Published on Reviews in History (https://reviews.history.ac.uk)

\title{
Review Article - Displaced Children in the Aftermath of the Second World War
}

Review Number: 2277

Publish date: Thursday, 6 September, 2018

Author: Christian Höschler

ISBN: 9783745059816

Date of Publication: 2017

Price: $£ 16.71$

Pages: 292pp.

Publisher: epubli

Publisher url: https://www.epubli.de/shop/buch/Homeless-Christian-H\%C3\%B6schler-9783745059816/63236

Place of Publication: Berlin

Author: Lynne Taylor

ISBN: 978-1487521943

Date of Publication: 2017

Price: $£ 25.50$

Pages: 480pp.

Publisher: University of Toronto Press

Publisher url: https://utorontopress.com/us/in-the-children-x2019-s-best-interests-2

Place of Publication: Toronto

Reviewer: Antoine Burgard

The relief and resettlement of Europe's unaccompanied and displaced children in the immediate aftermath of the Second World War has recently received considerable scholarly scrutiny. The two books reviewed here, while different in scope and methodology, are both welcome additions to the growing literature on the topic. Lynne Taylor's In the Children's Best Interests explores the story of the thousands - between 30 and 40 in 1945 - unaccompanied children that were in American-occupied Germany and examines the 'fierce international debates over their fates' (p. 5). Christian Höschler's Home(less) is a 'microhistorical study' of what the author describes as a 'unique humanitarian project' (p. 18): the Children's Village of Bad Aibling that was set up by the International Refugee Organization (IRO) also in the American occupation zone, 40 miles south-east of Munich. From 1948 to 1951, the facilities welcomed more than 2,300 children from various nationalities and backgrounds. The difference in scope might simply find its origins in the background of each work: In the Children's Best Interests is the result of a decade of research.(1) Home(less) is based on Höschler's PhD thesis submitted in 2016 at the University of Munich. Both books cover relatively the same period. Taylor's wider chronology is particularly relevant to connect the work of the United Nations Relief and Rehabilitation Administration (UNRRA) and the IRO. It is one of the many contributions of In the Children's Best Interests as the two organizations have been too often separated by the historiography. Both books draw on an impressive research in many archives - predominantly German and American-based, especially in the case of Home(less) - and on English, French and German scholarship - Höschler's engagement with existing literature being more systematic. 
After an introduction that provides an important reminder that the field of international child welfare "was not a tabula rasa' (p. 13) in the immediate aftermath of World War 2, Home(less) is structured in three chapters that chronologically cover the Village's 'three turbulent years' (p. 167) of existence: from the practical difficulties of its beginning in November 1948 to the transfer of the remaining children in another location near Munich in October 1951. The Village was opened in a former air-base and was the IRO's response to the difficulties encountered in other children's centres of the area. During its first months, Bad Aibling faced the same issues than elsewhere: inadequate facilities, lack of trained workers, and misunderstandings between the many organizations involved (the American Friends Service Committee, the Organization for Rehabilitation through Training, the Jewish Relief Unit, and the Young Men's Christian Association all had representatives there). The poor living conditions resulted in frequent - sometimes violent - tensions between the staff and the children and among the children themselves. The second chapter places more clearly Bad Aibling on the map of the broader post-war debates on how best to rehabilitate children - i.e. familialism or collectivism. It also situates the Village's experiments and policies - its recreational and educational programs as well as the medical and psychological support for the children - in the longer history of education and child welfare, especially by tracing the internationalist pre-war backgrounds of some of its workers. It provides a detailed account of the many challenges the workers faced by describing how they "constantly juggled the requirements of official regulations, the frustration of day-today restrictions, the influence of the contemporary zeitgeist, and their own ideals and expectations' (p. 134). The third chapter focuses on the last months of the Village. It examines the activities of the American High Commissioner for Germany (HICOG) and the growing tensions around the issue of repatriation and resettlement of unaccompanied children. It also highlights the complex interactions of the Village with the local German population. By doing so, Höschler challenges the idea that the facilities were 'parallel societies' and echoes Atina Grossmann's seminal work on the 'close encounters' between Germans and Jews.

The scope of In the Children's Best Interests are different. Taylor convincingly argues that the story of the 'unaccompanied children' is 'a story of a battle over children seen as national property, and one that reveals starkly the degree of confusion surrounding the notion of nationality' (p. 5). The efforts from many parties military and civilian authorities, aid organisations, etc. - to 'renationalise' children whose legal identities had been weakened by the war are the very centre of her book. She considers 'the mobilisation of national identity and national self-determination' as one 'fundamental rupture with the pre-war era' (p. 6). According to Taylor, this importance was not acknowledged by Tara Zahra in The Lost Children. The 'need for a legal identity based in citizenship, which would ensure that the children would have someone to protect them and advocate for them' was a 'key factor' that played a major role in determining what was the 'best interest' of unaccompanied children (p. 11). This need was complicated not only by the lack of evidence but also by the confusion between 'nationality (read: ethnicity) and citizenship' (p. 281) that prevailed in the aftermath of the war. By thoroughly documenting the debates that emerged from this tension, Taylor's book represents a crucial contribution that goes way beyond the sole studies of childhood in post-war Europe. It will surely inform the work of many scholars interested in citizenship and State regulation practices.

The book's thematic structure covers a wide range of issues. The first chapter is a long history of the UNRRA that is well-rounded but would have benefit from further engagement with the existing literature, especially the work of Jessica Reinisch. The second chapter offers an overview of the many European and international responses to the problem of unaccompanied children that came from England, France, or Switzerland. It deepens our understanding of the tensions between the various parties that claimed the responsibility of these children. The third chapter focuses on the beginnings of the child search, especially after the discovery of Lebensborn homes. The fourth chapter addresses the many legal issues - age of majority, adoption, guardianship, etc. - that arose from the situation of some children. Among other 
fascinating accounts, Taylor unravels the 'unique challenge' posed by children born from displaced person mothers, predominantly Polish nationals, and black GIs fathers. Their complicated fates strikingly illustrate 'a bigger problem, namely the large number of illegitimate children being uncovered' (p. 93). The fifth chapter explores the specific case of the populations that came illegally to the Western-occupied zones from Eastern Europe, the vast majority of them being Jewish, and that were dubbed 'infiltrees' or 'post-hostilities refugees' by administrations. Chapters six and seven address further complications that arose, first, from the increasing resistance from German institutions to the removal of children that were living with German families; second, from the opposition of UNRRA officers as well as British, French, and Soviet representatives at the Allied Control Authority (ACA) to the American-led initiative of deeming German the unaccompanied children whose nationalities were too unclear. This effort ultimately failed but represents a major shift in the US policy toward Europe's lost children. The eighth chapter explores the less-known work of the IRO, its battle with American authorities and the 'marked evolution' in its understanding of child search activities: the organisation gradually nuanced its ideal - family reunification - that became 'contingent on the legal rights of the child and relatives; on the willingness and ability of the family to care for the child, and finally, if the child was old enough, upon the child's own wishes' (p. 220). Chapter nine focuses on the last children, the 'residual', that posed severe problems and led to the creation of a children's court within the Germany-based American court system (p. 253). Nuancing the many accounts of failure, Taylor ends this chapter by acknowledging that, 'in light if the formidable challenges faced by these child search and welfare workers from the beginning, it is truly remarkable that they achieved all that they did' (p. 279), namely, the repatriation, resettlement, or absorption into Germany of approximately forty thousand unaccompanied children. The last chapter of her book further addresses the tensions between a 'civic' understanding of nationality - with an underlying assumption that 'political borders matched ethnic boundaries' (p. 280) - and an 'ethnic' (and therefore blurrier) definition. Taylor provides a useful overview of the implications of such tensions for various DP groups (Jewish, Baltic, Yugoslavian, Polish, etc.). She clearly points out the 'extraordinary treatment of Jewish DPs' that complicated the overall precedence of a 'civic' nationality over an 'ethnic' one: Jewish DPs had the choice to choose 'an ersatz nationality, that of "Jewish" - a category that came without citizenship and did not really reflect a true ethnic identity in the then-accepted sense' (p. 320). The consequences of these evolutions and debates over what nationality was would, of course, 'reverberate through the Cold War years and beyond' (p. 321). Taylor's book might have benefit from further engagement with other works on unaccompanied children - Ana Andlauer, Verena Buser, Boaz Cohen, and Joana Michlic among others $\underline{(2)}$ - but it convincingly achieves its ambition of complexifying the grand narrative that emerged from Zahra's work.

Not surprisingly, the predominant if not the only voices within the two books are the voices of adults. This absence calls for further research to acknowledge that children were not passive objects. Taylor is right to argue that children had little say but they still often managed to adapt, resist, and take over the categories set up by administrations. In Home(less), the detailed account of the workers' everyday struggle is insightful but Höschler's book would have gain for a more balanced analysis of the narrative that emerges from their correspondence, memorandums, and later testimonies. It would have been especially interesting to further address the underlying professionalising agenda that the author sometimes misses to acknowledge. For instance, the 'devastating report' (p. 59) of IRO's nutritionist Frances Berkley Floore or the 'reasonable conclusion' (p. 92) of Bad Aibling's director Douglas Deane also embody the battles for legitimacy and expertise between the many adults that claimed the responsibilities of these children.

Finally, the spatial frameworks chosen by both authors have their strengths and weaknesses. The children's centre as a scale of analysis enables Höschler to highlight the children's diversity of backgrounds and the tensions that resulted from it. Taylor also benefits from her choice of predominately focusing on the American Zone. By doing so, both books stand out from other studies that only address and isolate specific groups - i.e. Jewish, ethnic Poles, Ukrainians - or organisations. However, this scale tends to sometimes 
overshadow the children's backgrounds and the transnationality of their individual trajectories. In the case of Home(less), it would have also been interesting to further compare the activities of Bad Aibling with other child welfare projects of the same period to truly support the claim about the Village's unique and innovative nature that was made by its workers and that Höschler generally endorsed. Nevertheless, Home(less) is a vivid and thorough depiction of Bad Aibling's everyday life that provides an interesting illustration of the bigger picture described by Taylor. In the Children's Best Interests will undoubtedly be a valuable tool for anyone interested in the complex relations between nationality and citizenship. Both books illustrate how dynamic this field of research is. They will be of great interest for students and scholars that work on Europe's 'lost children', not only in the decade following the war but also of today as they admirably contribute in historicising many current debates about unaccompanied minors.

\section{Notes}

1. See for instance Lynne Taylor, 'Unaccompanied DP children in Germany, 1949-1952: lost in the shuffle', in Beyond Camps and Forced Labour: Current International Research of Survivors of Nazi Persecution. Proceedings of the international conference, London, 11-13 January 2006, ed. JohannesDieter Steinert and Inge Weber-Newth (Osnabruck, 2008). Back to (1)

2. Anna Andlauer, The Rage to Live: The International D.P. Children's Center Kloster Indersdorf 1945-46 (Weichs, 2012); Verena Buser, 'Displaced children: 1945 and the Child Tracing Division of the United Nations Relief and Rehabilitation Administration', The Holocaust in History and Memory, 7 (2014), 109-23; Avinoam Patt, Finding Home and Homeland: Jewish Youth and Zionism in the Aftermath of the Holocaust (Detroit, MI, 2009). Back to (2)

Source URL:https://reviews.history.ac.uk/review/2277

\section{Links}

[1] https://reviews.history.ac.uk/item/295099 [2] https://reviews.history.ac.uk/item/298237 